\title{
Mellem kunstig befrugtning og naturlig intelligens \\ Om skiftende betydninger af køn og kvalitet
}

\section{Af MetTe Bryld og Nina LyKke}

Har kon og kvalitet noget med binanden at gøre? Svaret er nej, nair vi lytter til Folketingets debat om oremarkning af professorater til kvinder. Ja derimod, nair Loven om kunstig befrugtning er på dagsordenen!

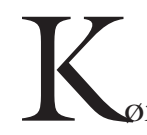

øn og kønsforskning har ikke haft den store bevågenhed i den politiske debat i Danmark i 1990erne. Efter afslutningen på Aktionsplanen for Kvindeforskning (1986-92) har mange kvinde- og kønsforskere oplevet, at det har været svært at råbe flertallet af danske politikere op. 1990erne har været kendetegnet ved en manglende politisk respons på de mange analyser, som forskerne fortsat har produceret. Er kønskampen ikke et overstået kapitel? Hvad bliver de kønsforskere dog ved at brokke sig for? synes mange politikere at tænke.

$\mathrm{Nu}$ og da bliver kønnets betydning dog alligevel sat på den politiske dagsorden. Vi vil i denne artikel se på, hvordan køn italesættes, når det sker. Vi vil lave en diskursanalyse af to folketingsdebatter, der begge har tematiseret forholdet mellem køn og kvalitet.

Først vil vi kaste et blik på debatten om forhenværende forskningsminister Jytte Hildens 11 punkts-plan til forbedring af 
kvinders stilling $\mathrm{i}$ forskningen og især det forslag om 40 øremærkede professorater til “det underrepræsenterede køn”, der lanceredes af Udvalget for Ligestilling i Forskning $(1998,15)$, som opfølgning på Hilden-initiativerne. ${ }^{1}$ Forslaget skabte stor furore, men afgik ved en stille død efter en forespørgselsdebat i Folketinget (F 21, 11.2. 1999), hvor et flertal mod øremærkning af professorater udkrystalliseredes.

Endvidere vil vi diskutere debatten om kunstig befrugtning, der fandt sted i 199698. Den satte, som de fleste nok vil huske, bl.a. fokus på spørgsmålet om lesbiske og enlige kvinder og endte med, at Folketinget med solidt flertal vedtog at diskriminere de to grupper ved at udelukke dem fra at fa lægelig bistand til kunstig befrugtning.

Vi vil analysere italesættelsen af forholdet mellem køn og kvalitet i de to debatter ved at se på forhandlingerne i Folketinget og den sideløbende diskussion i pressen. Det, der interesserer os, er at synliggøre et diskursivt paradoks, der kommer frem i sammenligningen af de to debatter.

Forholdet mellem køn og kvalitet synes nemlig ironisk nok at blive tilskrevet nærmest modsatte betydninger i de to tilfælde. Forslaget om at øremærke 40 professorater til kvinder strander, fordi det bliver udråbt til at være en alvorlig trussel mod forskningens kvalitet. Men hvor kvalitet således tilsyneladende stadfæestes som et kønsneutralt fænomen i forskningen, så mener folketingsflertallet åbenbart, at det modsatte er tilfældet, når der er tale om børn og deres opfostring. Her bliver køn - tilstedeværelsen af en far - fremhævet som afgørende for barnets tarv uanset kvaliteten af det familieliv, som faderløse familier måtte kunne fremvise. Et navngivent y-kromosom forlener ifølge det politiske flertal barnets liv med en kvalitet, som ingen moder kan give. I det følgende vil vi lade betydningsforhandlingerne i disse to fortællinger om køn og kvalitet gensidigt dekonstruere hinanden.

\section{FØRSTE FORTÆLLING OM KØN}

OG KVALITET:

DEBATTEN OM ØREMÆRKEDE PROFESSORATER TIL KVINDER

Debatten om køn og kvalitet i forskningen blusser op i Jytte Hildens tid som forskningsminister. Med debatoplægget "Kvinder, kvalitet, forskning" provokerer ministeren forskningsverdenen ved at betone en sammenhæng mellem køn og kvalitet: "Der er ikke kvinder nok i dansk forskning. (...) Kvinder er en vigtig ressource til styrkelse af forskningens kvalitet" (Forskningsministeriet 1997,5$)$. Videre betones det, at ikke mindst kvindeandelen i toppen af det akademiske hierarki er katastrofalt lav (kun 6\% kvindelige professorer), når den formelle og uformelle magt og indflydelse, der ligger på professorniveau, tages i betragtning. Der henvises til den svenske undervisningsminister Carl Thams initiativ til oprettelse af 30 professorater til kvinder, og da Jytte Hilden samtidig - med bevillingen af 78 millioner kr. til det såkaldte FREJA-program (Female Researchers in Joint Action) - viser, at hun har til hensigt at sætte handling bag ordene om at fremme kvinders muligheder for deltagelse på alle niveauer i dansk forskning, bliver der for alvor rejst børster i forskningsverdenen. En eksplosiv politisk debat om køn og kvalitet er igangsat. Skal køn nu have prioritet frem for kvalitet i forskningen? lyder det fra et forarget kor af stemmer.

Folketingets debat om 40 øremærkede professorater til kvinder, der, foranledigt af socialdemokratiets forskningspolitiske ordfører Lise Hækkerup, finder sted 11. 2. 1999 (F 21), bliver sidste kapitel i den dramatiske fortælling om Hilden-initiativerne. Forud er gået et ministerskifte i foråret 1998, der midlertidigt får de forargede elementer i forskningsverdenen til at ånde lettet op for igen at gøre klar til stillingskrig sidst på året. Her viser det sig nemlig, at den ny forskningsminister Jan Trøjborg tilsyneladende er indstillet på at videreføre dele af Hildens politik og bl.a. støtte oprettelsen af de famøse professorater til kvinder, 
dog nedtonet fra faste til åremålsbegrænsede stillinger.

Når vi betragter forespørgselsdebatten i Folketinget, er det tydeligt, at den er påvirket af de forudgående indlæg i pressen, hvor repræsentanter for mainstream i dansk forskning har udråbt forslaget om øremærkede kvindeprofessorater, "discountprofessorater" (Grodal \& Grodal 1998), til at være en alvorlig trussel mod kvaliteten i dansk forskning. Forskningsministeren, der før jul har været positiv over for øremærkningen, er således ved debatten i februar blevet meget forsigtig. Han undgår i første omgang at nævne de 40 professorater, og da debatten til sidst aftvinger ham en stillingtagen, henviser han forskrækket til, at det nok ikke er hensigtsmæssigt at overføre den svenske Tham-model til Danmark, da forslaget herom har givet "unødig uro og debat" (F 21, 3781). Kun Lise Hækkerup (S) og Elisabeth Arnold (RV) støtter i deres ordførertaler forslaget helhjertet, mens ordførere for flere borgerlige partier til gengæld er endog meget tæt på ordlyden i de kronikker mv., som forskningsverdenens svorne modstandere af kønsøremærkning har offentliggjort op til forespørgselsdebatten. Karen Rønde (V) hæfter sig f.eks. ved, at det er "uværdigt, hvis kvinder skal ansættes på særlige kvoter” (F 21, 3769). Her lyder et ekko af de følelsesladede argumenter, som bl.a. få dage forinden er blevet fremfort i Politiken af Lise Hannestad og Birgit Nüchel Thomsen (1999), der med henvisning til mangeårige erfaringer fra arbejde $\mathrm{i}$ de danske forskningsråd advarer mod den “apartheidstatus for kvinder", som øremærkningen af professorater efter deres opfattelse vil medføre. I Karen Røndes ordførertale høres ligeledes genklangen af en kronik i Politiken af professorerne Birgit og Torben Grodal, der har kaldt forslaget om øremærkning af professorater for en "hån mod og devaluering af" de kvindelige forskere, der ikke vil "benytte (deres) køn" til at få stillinger "med rabat", og som modsat de evt. kommende indehavere af de øremærkede “discountprofessorater" - har kvalificeret sig "på normal vis” (Grodal \& Grodal 1998).

Som et direkte ekko af Grodal-parrets kronik fremhæver også Klaus Kjær (DF), at hele miseren med det lave antal kvindelige professorer har historiske grunde. Den er simpelthen en afspejling af kønsarbejdsdelingen i 1970erne og i bund og grund kvindernes egen skyld. Dengang var kvinder angiveligt endnu ikke så motiverede for at påtage sig job med langsigtede karrieremål, herunder forskningsjobs. Som Grodalerne siger, “besværliggør” sådanne karriereprojekter jo "et normalt privatliv, herunder tid til børn” (Grodal \& Grodal 1998), og da det ifølge de to professorer normalt tager 20-30 år at producere en professor, så er det en naturlig følge af de unge kvinders holdninger i 1970erne, at der i slutningen af 1990erne endnu ikke er ret mange kvalificerede kvinder, der kan søge professoraterne. Men der er ifølge både Kjær og Grodalerne grund til optimisme. Hvor de unge kvinder, der i 1970erne (kvindeoprørets og Rødstrømpebevægelsens årti (!)) strømmede ind på de masseuniversiteter, der var under dannelse, - ifølge Kjærs og de to professorers fortolkning af historien og forskningsstatistikken - samtidig dog klyngede sig til den traditionelle kønsarbejdsdeling, har de til gengxld i 1980erne og 90erne kastet gamle dages åg fra sig. Det har givet sig udslag i et stigende antal unge kvinder i forskningen og på professorniveau kan en stigning $i$ antallet af kvindelige professorer på hele $50 \%$ noteres for perioden 1991-95. Hvilken fremgang - fra 4 til hele $6 \%$ !

I Grodal \& Grodals, Nüchel Thomsen \& Hannestads og en række folketingsmedlemmers version af den dramatiske beretning om forholdet mellem køn og kvalitet er hovedskurken Jytte Hilden, der har sat politisk fokus på forskningen helt uvedkommende kønspolitiske synspunkter, og som vil fremtvinge en ændring før der historisk er basis for den $\mathrm{i}$ form af tilstedeværelsen af 
professorkvalificerede kvinder. Hertil kommer på skurkeholdet desuden kvinde- og kønsforskerne. Hos Nüchel Thomsen og Hannestad udråbes de som en grisk og paranoid interessegruppe, der målbevidst ødelægger dansk forskning ved at prioritere køn frem for kvalitet, og som ovenikøbet har haft en vis succes med deres skumle virke, idet de har "formået at skaffe sig særprivilegier og bedre vilkår end de kvinder, der arbejder på andre forskningsområder" (Nüchel Thomsen \& Hannestad 1999). Heltene i historien er til gengxld de, der heroisk forsvarer kvaliteten i dansk forskning mod de onde feministers kønslige forurening af det neutrale kvalitetsbegreb. Endelig er de, som kampen står om, de unge fremadstræbende kvinder, der stålsat baner sig vej i Akademia uden særprivilegier og billige henvisninger til deres køn, men som dog, ironisk nok, samtidig beskrives som uselvstændige og passive objekter, der er nemme at lokke og skræmme. Feministernes påståede sirenesang om en "mandlig sammensværgelse" mod at få kvinder ind $\mathrm{i}$ Akademia og "onde mandlige opfindelser" som "(internationale) videnskabelige normer" kan således ifølge Grodalerne let "afskrække de unge kvinder (...) fra at gå ind i en forskerkarriere" og forlokke dem til "at forkaste berettiget og konstruktiv kritik af deres forskningsresultater" (Grodal \& Grodal 1998).

I denne truende situation, hvor sågar Danmarks omdømme i udlandet ifølge Grodalerne er i fare, må alle gode kræfter "naturligvis" stå sammen og værne om det synspunkt, at køn og kvalitet er to helt adskilte størrelser, som det er direkte skadeligt, nedværdigende for forskerne og nedbrydende for forskningen at bringe $\mathrm{i}$ berøring med hinanden. Eller som Dansk Folkepartis ordfører med stor patos fastslår: "Det må imidlertid aldrig blive således, at det er de kønspolitiske synspunkter, som bliver afgørende for fastsættelsen af kvaliteten og de internationale standarder og normer for forskning” (F 21, 3774).
Ud over avisindlæg fra modstanderne af forslaget om øremærkning optræder også Undervisningsministeriets rapport om køn i dansk universitetsforskning (Ståhle 1998) som en yndet referenceramme i folketingsdebatten. Ståhle-rapportens konklusion, at kvinder opnår 49\% af de adjunkt-, lektorog professorstillinger, hvor begge køn er representeret blandt de kvalificerede ansøgere, bliver af en række folketingsmedlemmer brugt til at betone, at det går fremad. En del hæfter sig dog også ved det beklagelige i, at kvinderne kun fik $27 \%$ af de opslåede stillinger i 1995-96, fordi der til mange stillinger ikke var kvindelige ansøgere.

Men at det endvidere ifølge Ståhle kun er på adjunkt- og lektorniveau, at kvinder får ca. halvdelen af stillingerne, når der er kvalificerede ansøgere af begge køn, er der ingen, der tager notits af. At det ser markant anderledes ud ved stillingsbesættelserne på professorniveau, giver ikke anledning til debat. Her får kvinderne ifølge Ståhle ellers kun $27 \%$ af de stillinger, der har både kvindelige og mandlige ansøgere. Ståhle forklarer dette med, at der er få kvindelige ansøgere $\mathrm{i}$ forhold til mandlige $(1,1 \mathrm{i}$ forhold til 5,5), men samtidig må han konstatere, at det ikke kan være hele forklaringen på deres lave succesrate. For det første har kvinder nemlig på adjunkt- og lektorniveau făet en relativt større del af stillingerne, end man skulle forvente ud fra deres numeriske andel af ansøgerskaren, hvilket rejser spørgsmålet, hvorfor det samme ikke er tilfældet på professorniveau. For det andet må Ståhle konstatere, at kvinder på professorniveauet ikke simpelt hen scorer proportionalt med deres andel af ansøgerskaren, men at de faktisk får en relativt lavere andel af stillingerne. Især ved besættelsen af humanistiske professorater ser der ud til at være problemer. Her, konkluderer Ståhle, var "kvindeandelen i ansættelserne iøjnefaldende svag" (Ståhle 1998, 225). Eller med andre ord: Hvis folketingsflertallet ville have haft argumenter for øremærkning af pro- 

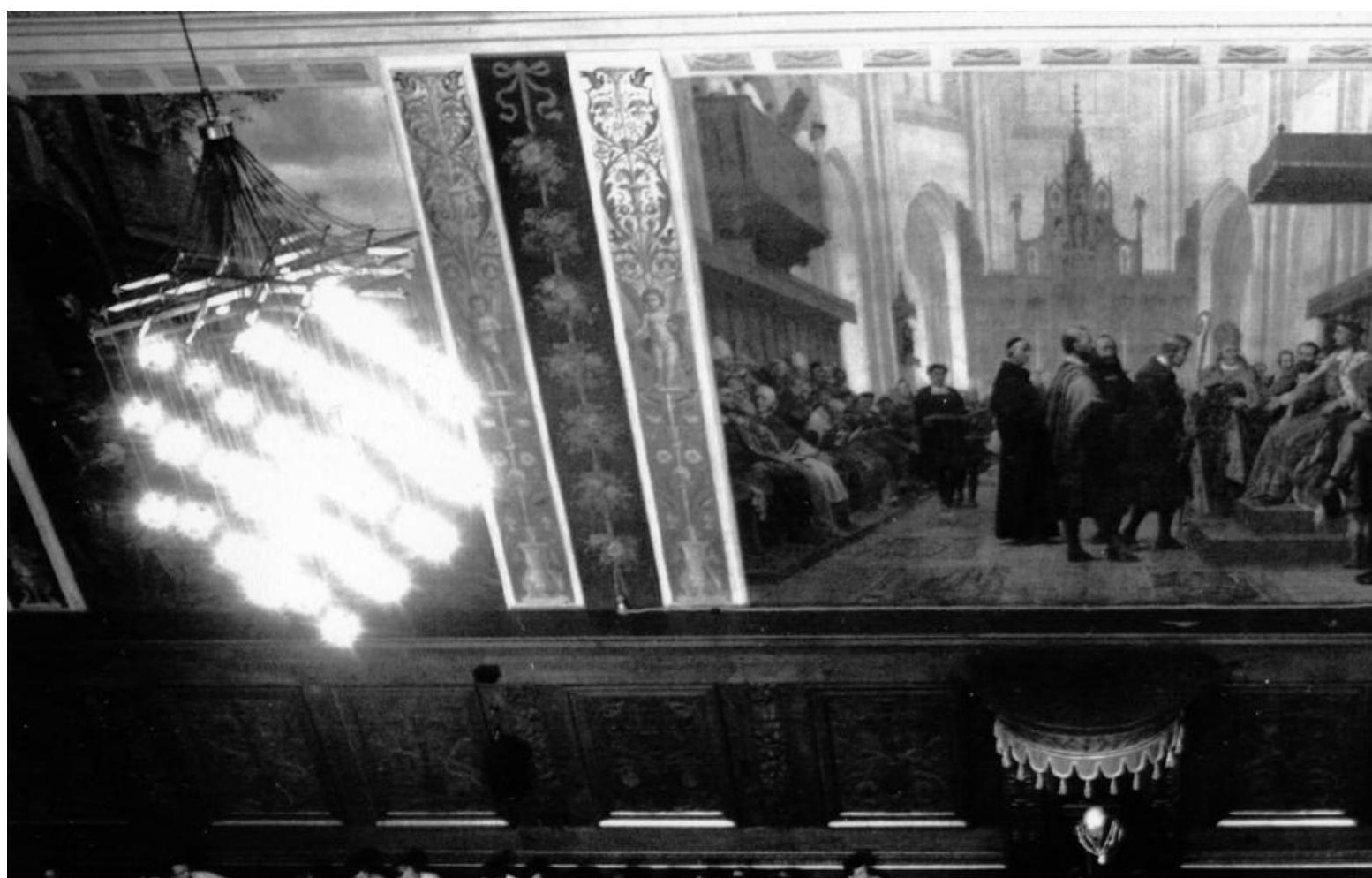

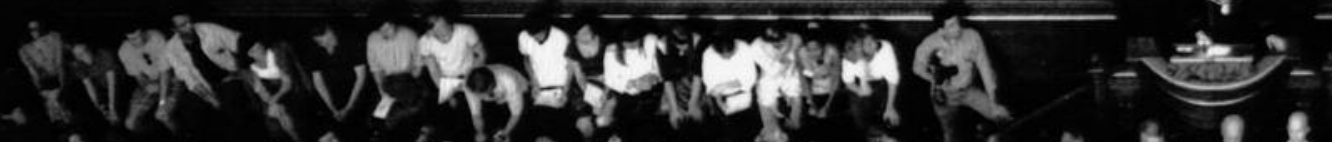

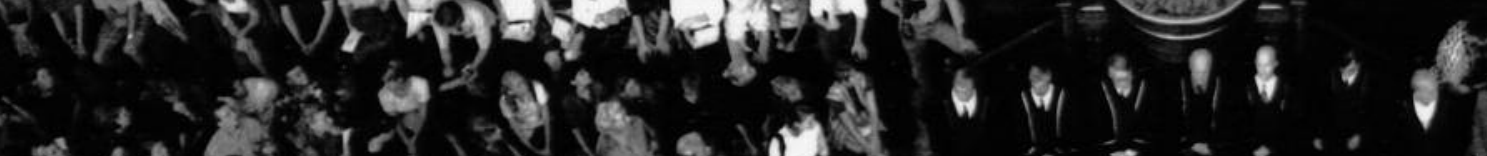

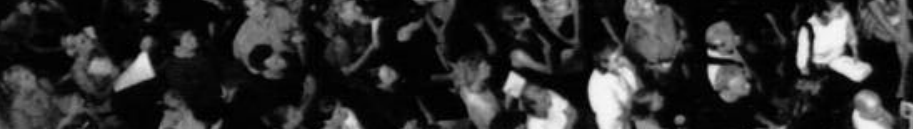

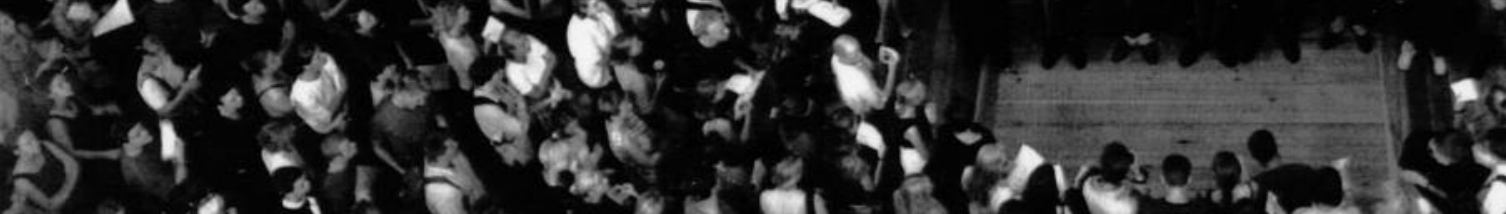

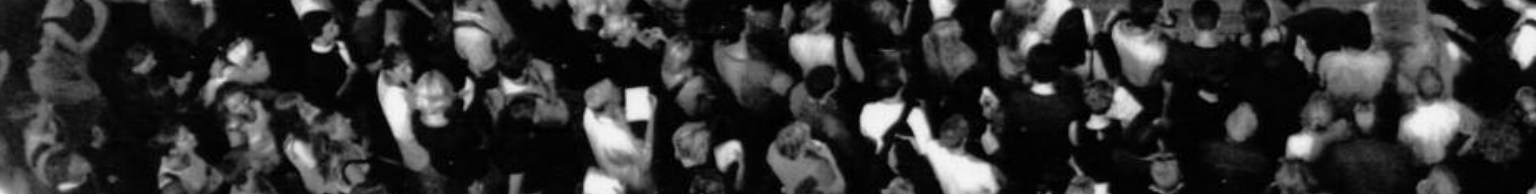

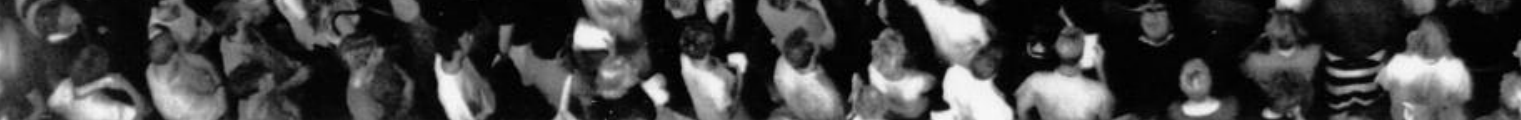

Immatrikulationsfest på Kobenhavns Universitet 1999. Kjeld Mollgärd hilser på de nye studerende. Foto: Thomas Borberg 


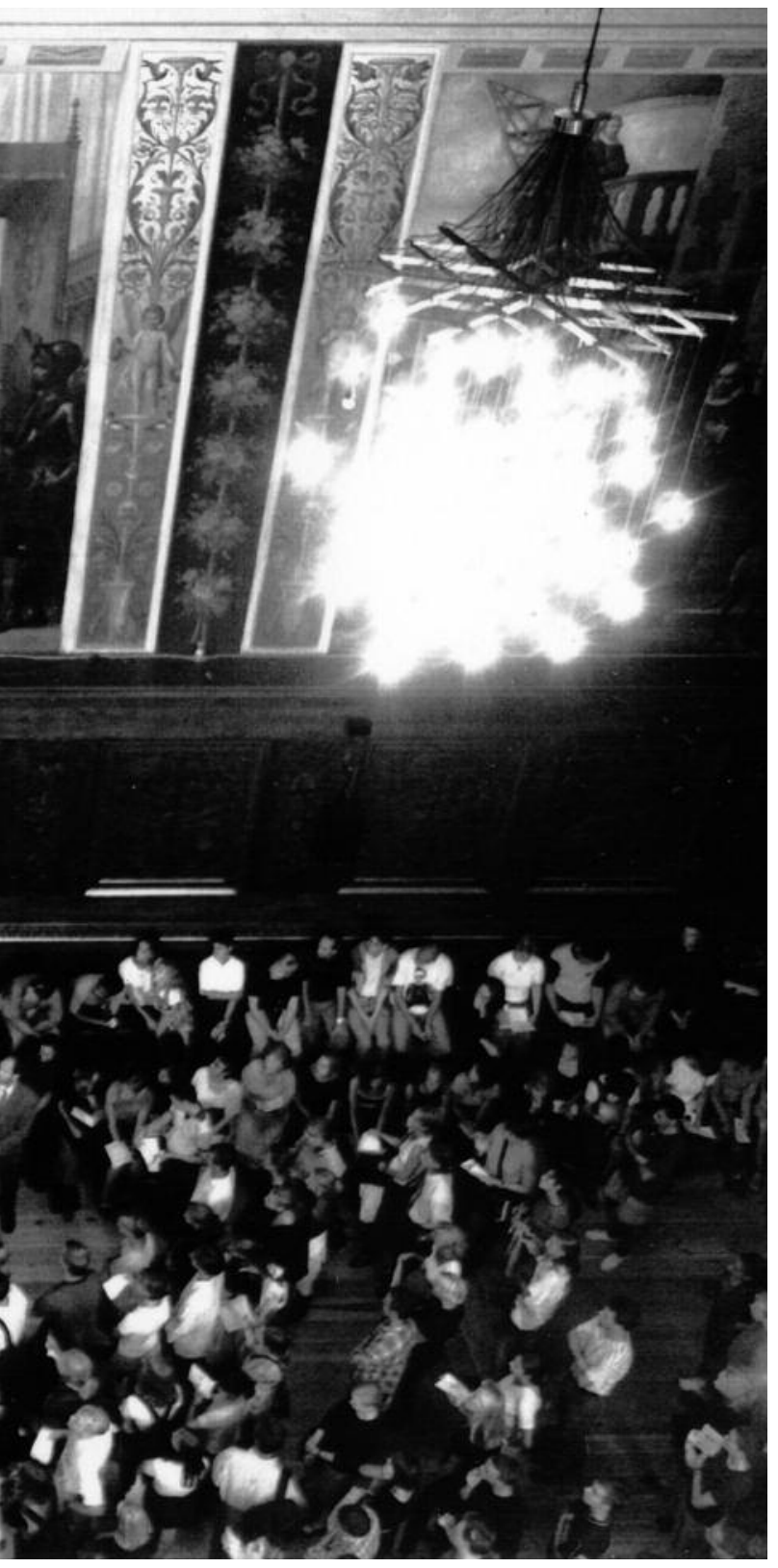

fessorater, kunne de have fundet dem hos Ståhle, men det gør de ikke!

Vi kan naturligvis kun gætte på grunden hertil. Men mon ikke det, forskningsministeren eufemistisk kalder "unødig uro og debat" (F 21, 3781) - det, at forskningsverdenens mainstream har kaldt til samling om et depersonaliseret, universelt kvalitetsbegreb og samtidig mere end antydet det beskæmmende element af discount, som professorater, som "kun" kvinder kan konkurrere om, "naturligvis" må være behæftet med - har gjort sin virkning?

\section{ANDEN FORTÆLLING}

OM KØN OG KVALITET:

DEBATTEN OM KUNSTIG BEFRUGTNING

Mens vor første fortælling lagde op til den konklusion, at køn ikke har noget med kvalitet at gøre, og at en for stærk insisteren på kvindekøn måske ligefrem kan afføde en kvalitetssænkning, "discount”, så demonstrerer den anden fortælling med al ønskelig tydelighed, at mandskøn til gengæld i sig selv indebærer et kvalitetsløft. Det kommer frem i løbet af den debat, som starter i Folketinget efter, at daværende sundhedsminister, Yvonne Herløv Andersen, fremsatte sit forslag til "lov om kunstig befrugtning i forbindelse med lægelig behandling, diagnostik og forskning m.v." i februar 1996 (L 200). ${ }^{2}$

Lovforslaget er det første af sin art i Danmark. I årevis var hele dette mangefacetterede område reguleret alene af en lov om biomedicinske forskningsprojekter og af forskellige cirkulærer, vejledninger mv., der ikke skilte bestemte grupper fra. Det gjorde derimod de regler, som amterne, sygehusenes lokale bosser, selv opstillede. Her blev det fastslået, at kun kvinder i længerevarende, heteroseksuelle parforhold kunne få adgang til en behandling for "ufrivillig barnløshed" i offentligt (og gratis) regi. Udelukket fra det offentlige system, måtte alle andre - enlige og lesbiske - derfor ty til private klinikker og selv betale, hvad det koster. 
I forhold til spørgsmålet om, hvem der kan behandles, lagde Herløv Andersens lovforslag fra 1996 egentlig blot op til en videreførelse af den eksisterende praksis. Alle kvinder i den reproduktionsdygtige alder kunne ifølge lovforslaget behandles, men underforstået var det så sandeligt også, at amterne fortsat kunne afvise alle dem, der ikke levede sammen med en mand. Nu som før ville enlige og lesbiske være henvist til det private behandlingssystem, nu som før ville de selv komme til at betale. Men som det snart skulle vise sig, var det slet ikke nok for de mange fanatiske 'far-mor-barn'tilhængere i Folketinget. Det var ikke nok hverken i den første fase, som endte i slutningen af maj 1997, da loven og den paragraf $(\$ 3)$, der direkte forbyder læger i både det offentlige og private behandlingssystem at give kunstig befrugtning til enlige og lesbiske, blev endeligt vedtaget (Lov nr. 460 af 10. 6. 97 - loven trådte i kraft d. 1. 10. samme år). Og ej heller i den anden og sidste fase, hvor nogle enkelte folkeltingsmedlemmer med bl.a. Anne Baastrup (SF) i spidsen gjorde et helhjertet, om end forgæves forsøg på at få omgjort det skandaløse forbud. I juni 1998 forkastedes deres ændringsforslag med 70 stemmer imod og 57 for. Med andre ord: Hvad der havde være tilladt for alle kvinder i en nogenlunde velafgrænset aldersgruppe, blev i 1997 forbudt for den store gruppe af kvinder, der ikke "lever sammen med en mand i et $x g$ teskabslignende forhold" $(\$ 3)$. Det biologiske mandskøn blev hermed gjort til afgørende instans i vurderingen af, om det kvindelige begær efter et barn var legitimt eller ej. ${ }^{3}$

Behandlingen af lovforslaget foregik selv sagt $\mathrm{i}$ alt andet end et tomrum. Mange folketingsmedlemmer var tydeligvist dybt foruroligede over avisernes talrige sensationshistorier fra det reproduktionsteknologiske overdrev, hvor 'naturen' syntes at være sat helt ud af spillet. Den italienske kvinde, der blev mor (og ikke bedstemor) i en alder af 63 år, spøgte i flere indlæg. Det amerikan- ske system med dets kommercialisering af stort set alt fra xgdonorer til surrogatmødre fungerede som et andet skræmmebillede. Og bedre blev det ikke, da klonfăret Dolly, skabt gennem énkønnet reproduktion, gjorde sin entré midt i det hele (februar 1997). ${ }^{4}$ Hvad kunne være mere velegnet til at dæmme op for den natur-erosion, som teknologien og nogle uansvarlige videnskabsfolk havde sat i gang, end en radikal tilbagevenden til det 'naturlige'? Til far-mor-barn-familien?

Hans Peter Baadsgaard (S) udtrykker det klart: "Det kan ikke altid lykkes i menneskelig adfærd at sikre et barn en far og en mor, men jeg synes, at når vi herindefra skal lave regler for en virksomhed, skal vi nærme os det naturlige så langt som muligt. Det er nu en del af vores familieliv, en del af vores menneskesyn, det er en del af barnets hele opvækst, at barnet har en far og mor." (29. 4. 97, L 5, 6376) Hvad Baadsgaard så glimrende får afdækket i dette citat er, at den kamp, han selv var med til at starte, for at udelukke enlige og lesbiske fra lægelig behandling, nok så meget handler om "vort menneskesyn" og om en bestemt type kernefamilies evige 'naturlighed' som om det gummi-begreb, "barnets tarv", som Folketingets naturlighedsdyrkere ellers klyngede sig til.

At det 'naturlige' måtte bygge på en mandskønnet far, kunne flertallet let blive enig om. Hvorvidt det var en biologisk eller en social far, syntes mindre afgørende, blot det var mandskøn. Preben Rudiensgaard (V) er f.eks. "af den opfattelse, at et samvær med, man kan sige - et y-kromosom - en rigtig mandlig part" ofte var af stor betydning for en drengs identitet (dog skulle dette $y$-kromosom helst ikke stamme fra Fjernøsten!) (24. 4. 98, L 53, 771). Margrethe Auken insisterer på sin og rystende mange SFers side på indsættelsen af den biologiske far gennem fadernavnet: "Har enlige kvinder ret til at få børn, uden at der et eller andet sted i den anden ende af sædklatten er et navn?", spørger hun ret- 
orisk (8. 10. 96, L 5, 248); Henriette Kjær (KF) begrunder sin afvisning af at slette kravet om heteroseksuelt samliv med et bombastisk: "vi ser ingen grund til, at staten direkte skal være med til at skabe et fædreløst samfund" (21. 1. 98, L 61, 3176).

Sammenhængen mellem kvalitet og mandskøn kommer måske klarest til udtryk ved en gennemgang af de vidt forskellige billeder, som Folketingets talrige naturlighedsdyrkere med formynderisk ildhu opstiller af hhv. kvinder og mænd. Mens kvinder overvejende aftegnes negativt, gælder det modsatte for (rigtige) mænd. De følgende fem eksempler illustrerer galleriet af kvindetyper.

Først er der den slags kvinder, der på den ene eller anden måde er naturens misfostre, og som derfor enten ikke "kan" eller ikke "vil". Det er hende, der er så "ufattelig grim", at hun ikke kan "score en mand". Skulle hun - eller den lesbiske, der jo ikke vil "score en mand" - virkelig have adgang til en "sædklat" uden navn? (M. Auken, 8. 10. 96). Så er der, for det andet, Karrierekvinden. Hende, der af rent egoistiske grunde udskyder et barn, indtil det er ved at være så sent, at hun måske ikke kan nå at finde en fyr. Hun er klart nok en 'selvisk' og slet person uden de rette moderinstinkter. For hende, hvis livsstil sikkert har konsumtion som sit omdrejningspunkt, er barnet et rent forbrugsgode (jf. Anne-Marie Hansen (S), 21. 1. 98, L 61, 3191). Den tredje type er i en vis forstand Karrierekvindens modsætning. Hun er den svage, uselvstændige kvinde, som "man skubber ind i ... behandling” (M. Auken, 29. 4. 97, L 5, 6352). Det er hende, der ikke kan sige fra, og som blot er et passivt objekt, et offer for andres (skumle) aktiviteter. "Der er ingen grund til at lokke kvinder ind fra gaden som [xg]donorer og sætte dem i gang med en smertefuld behandling, så de skal sygemeldes fra deres job" (H. Kjær, 27. 5. 97, L 5, 7809-10). Når xgdonoren aflægger passiviteten og i stedet spiller rollen som selvstændig aktør, siver der imidlertid et skær af det fordækte og tvivlsomme ind $\mathrm{i}$ sceneriet. Der ligger således noget dubiøst, noget anonymt og relationsløst over den kvinde, der selv kan "gå ind fra gaden" og melde sig som donor. "Ifølge lovforslaget vil man have, at kvinder også skal kunne gå ind fra gaden og være donorer, og det er vi imod" (H. Kjær, 29. 4. 97, L 5, 6361). Endelig er der til sidst de lesbiske. Af dem er der to slags: de ansvarlige, der gør deres bedste for at skabe noget, der kan ligne en naturlig far-mor-barn-familie. Det er nemlig helt i orden, også selv om faderen er bøsse, så længe de bare ikke forventer lægehjælp til insemination, reagensglasbefrugtning mv. Har de lukkede æggeledere, ja så må de naturligvis enten resignere eller blive 'normale'. Den anden slags lesbiske er selvsagt de uansvarlige: dem, der lever i den vildfarelse, at de kan varetage deres barns "tarv" uden et y-kromosoms fysiske eller symbolske tilstedeværelse (fadernavnet). ${ }^{5}$

Mens disse kvindekonstruktioner suger næring af den kvindeforagt, der er indeholdt i vor kultur, læner mandsbilledet sig op ad traditionelle maskulinetsforestillinger. I forgrunden står ikonet, den 'gode' far. Det er ham, hvis mandlige udstråling er så stærk, at han end ikke behøver at være hjemme. I M. Aukens romantiserede omkvæd fremstår han som drømmeprinsen: "Et barn har ret til en far, og det bør ikke kun gxlde, når forældrene går fra hinanden, men også når barnet bliver til. At faderen kan glimre ved sit fravær, ved vi godt, og det kan vi ikke lovgive os ud af, men vi kan i det mindste sikre, at der er en, der glimrer. Der skal være en at drømme om og længes efter, ellers er det dog helt forfærdelig sørgeligt.” (29. 4. 97, L 5, 6353) Modbilledet til denne drømmeprins er den 'defekte' (kastrerede) mand, der også er et af naturens misfostre. Det er ham, hvis sædceller er så "vakkelvorne", at de "ikke engang kan gå selv", men må "køres frem i kørestol og skubbes ind" (M. Auken 16. 6. 98, L 53, 2000). Han borger i modsætning 
til den overdeterminerende drømmeprins ikke for kvalitet. Derfor optræder denne marginal-han da heller ikke så hyppigt som prinsen.

Ud over det 'naturlige' kunne naturlighedsdyrkerne hente deres alibi i FNs børnekonvention, der nævner 'barnets ret til en mor og en far'. Det er også den konvention, der skal legitimere det nye lovforslag, som vil tvinge kvinder til at opgive navnet på barnets biologiske far. Professor, dr. jur. Eva Smith fortolker interessant nok denne konvention på en anden måde end Folketingets flertal. I en kronik i Berlingske Tidende skriver hun: "Mon børnekonventionen sigter snævert på den biologiske far? Mon ikke der tænkes på den sociale far hvad enten han er biologisk, adoptivfar, far til et donorbarn, hvor en anden har leveret sæden - eller maiske en kvinde, hvis barnet vokser op $i$ et lesbisk forhold" (vores kursiv; Smith 2000). Eva Smith har tydeligvist ikke fattet den ubrydelige sammenhæng mellem mandskøn og kvalitet.

\section{KAN FORSKNING OG FAMILIELIV SAMMENLIGNES? ELLER: HVAD ER ET HJEM UDEN EN FAR?}

Hvad kan vi lære af vore to fortællinger om køn og kvalitet? Ja, som vi skrev i indledningen, tematiserer de forholdet mellem køn og kvalitet meget forskelligt. Lige så forurenet og devalueret kvalitetsbegrebet åbenbart blev, da Jytte Hilden og kønsforskerne bragte det i berøring med køn i den første fortælling, lige så skadeligt og nedbrydende for kvaliteten var det øjensynligt i den anden fortælling at hævde, at kønnet var ligegyldigt. Det umiddelbare budskab i vore to fortællinger er, at i forskningsverdenen er kønnet ligegyldigt for kvaliteten, i familielivet derimod er det essentielt.

Men da forskning og familieliv jo unægtelig repræsenterer to forskellige livssfærer, er det måske heller ikke så mærkeligt, at der opereres med forskellige kvalitetsbegreber? Nej, ikke hvis fortællingerne kun havde drejet sig om kvalitet. De diskursive paradokser opstår, fordi begge også involverer passionerede forhandlinger om betydninger af køn.

Kvalitetsbegreberne i de to fortællinger forankres således i nogle primitive og indbyrdes modstridende diskurser om forholdet mellem køn og kvalitet. I det ene øjeblik ligegyldiggøres og deessentialiseres kønnet, mens det i det andet essentialiseres og tingsliggøres, og denne begrebsforvirring inficerer de kvalitetsbegreber og normer, som folketingsflertallet i de to fortællinger prøver at knæsætte. Anskues køn nemlig principielt som en ikke-essentiel kategori, som den første fortælling gerne vil fastslå, så burde det være udgangspunktet, uanset om det er køn, kvalitet og normer for forskningen eller for familielivet, der tales om. Opfattes kønskategorien derimod som noget essentielt, en essentiel mandlighed og en herfra forskellig essentiel kvindelighed, som den anden fortælling pukker stærkt på, så burde det på samme måde have været gjort gældende ikke kun, når det drejede sig om kvalitetskriterier og normer for familielivet, men også for forskningsverdenen! Eller med andre ord: Folketingsflertallet ville have haft gavn af et grundkursus i kønsforskningens helt banale og grundlæggende begreber om konstruktion og essens, før det kastede sig ud i at opstille regler og formulere normer for forholdet mellem køn og kvalitet.

Men ud over at sammenstillingen af vore to fortællinger peger på, at der er behov for mainstreaming af kønsforskning, i betydningen: bred skoling af samfundet i kønsteoriens $\mathrm{ABC}$, så synliggør den desværre også endnu et forstemmende aspekt af folketingsflertallets opfattelse af forholdet mellem køn og kvalitet. Den åbenlyse tendens, som vi så i den anden fortælling, til at tilskrive mandligheden et kvalitetsprimat, kan nemlig også spores som en understrøm i den første.

En af Ståhle-rapportens konklusioner går ud på, at der til mange professor-, lektor- 
og adjunktstillinger kun var mandlige ansøgere, og at stillingerne tit besættes stort set uden konkurrence, idet der i halvdelen af tilfældene højst var to ansøgere og ofte kun en (Ståhle 1998, 19). I debatten giver dette anledning til beklagelser over kvinderne, der ikke søger. Hvad det derimod betyder for forskningens kvalitet, at der er mange stillinger, som besættes stort set uden konkurrence, er der ingen (bortset fra enkelte feminister, f.eks. Henningen 1999), som spørger bekymret om. Her råber forskningsverdenens mainstream ikke "discount" så højt, at det giver genlyd i Folketinget! Hvorfor? Skulle det mon være, fordi det, at det fortrinstvist er mand, der besætter disse stillinger, med en underforstået og ubevidst automatik også aktiverer den forestilling, at det i sig selv borger for kvaliteten? Hvad er ellers grunden til, at ramaskriget kun rejser sig, når det markerede køn, kvinder, selv skal sætte standarden for kvalitet gennem indbyrdes konkurrence?

FREJA-projektet, der med sit rekordhøje ansøgningstal på 327 , viste, at øremærkning og en særdeles hård konkurrence, der sætter et højt kvalitetsniveau, udmærket kan gå hånd i hånd, kunne ikke få det vedholdende kor til at holde op med at råbe "discount". Derfor er det svært ikke at drage den forstemmende konklusion, at det åbenbart ikke kun er i familielivet, at Folketingets flertal ønsker at knæsætte Faderloven, men at Lacans udsagn om fallos som værdimålestok for alting åbenbart også virker i det skjulte, når spørgsmålet om kvalitet i forskningen står på den politiske dagsorden. de tid. Om hun nogensinde måtte få tid, står hen i det uvisse. Vi skal i øvrigt bemærke, at sagen er meget aktuel, eftersom Loven om kunstig befrugtning nu igen er blevet sat på Folketingets dagsorden. Målet med xndringen (L 183, fremsat af Sundhedsminister Carsten Koch 2.2.2000) er først og fremmest at fă forlænget opbevaringstiden for befrugtede og ubefrugtede $x g$ fra to til fire år.

3. Som i det følgende, fantastiske eksempel italesættes sædens privilegerede position, selv når den stammer fra en anonym donor. I deres svar på en forespørgsel fra Sygehusledelsen for Århus Kommunehospital om deres afdeling kan tilbyde donorinsemination til lesbiske, skriver overlæge, $\mathrm{dr}$. med. Hans Jakob Ingerslev og adm. overlæge Niels Jørgen Secher d. 9. 6. 1994: "Hensynet til donorernes ønsker bør medtages i disse overvejelser [om hvorvidt lesbiske kan få adgang til insemination]. I en spørgeskemaundersøgelse blandt sæddonorer i sædbanken Cryos svarer $30-40 \%$ af donorerne, at de accepterer, at deres sæd anvendes til insemination af lesbiske, mens ca. $40 \%$ er direkte imod." Brevet kan sammen med andet værdifuldt materiale i dette sagskompleks rekvireres fra Landsforeningen for Bøsser og Lesbiske. I modsætning til vor egen Forening for Kvinde- og Kønsforskning tog Landsforeningen aktivt til genmæle mod den diskrimination af enlige og lesbiske, der blev indsat i loven.

4. Dolly blev skabt ved, at en celle fra 'moder' fårets yver blev indsat i et 'tømt' æo fra det får, som siden bar og fødte Dolly. Ikke overraskende er dette afkom opkaldt efter Dolly Parton!

5. Da jordemor Stork åbnede en klinik i København, hvor enlige og lesbiske kan få hjælp til insemination, lød der et ramaskrig fra bl.a. M. Auken og H. Kjær, som straks forlangte sundhedsministeren i samråd med henblik på en lukning af klinikken. Selvom de naturligvis udmærket vidste, at loven alene forbyder læger at udføre behandlingen, hævdede de, at jordemorens initiativ var helt i strid med lovens "ånd" (jf. TV2 Nyhederne 27.9.99). Det har de for så vidt ret i! For loven handler ikke om kvinder eller børn, men om y-kromosomets privilegerede position.

\section{LITTERATUR}

- Folketingets Arkiv, Folketingssamlingen 199899, Forespørgsel F 21: Forespørgsel til forskningsministeren - "Hvad vil ministeren foretage sig for at sikre en større kvindelig repræsentation i forskerverdenen, således at der bliver større lighed mellem andelen af kvindelige og mandlige forske- 
re, professorer m.v.?”, Udskrifter 11.2. 1999: pp. 3764-3781.

- Forskningsministeriet (1997): Kvinder, kvalitet, forskning, Forskningsministeriet, København.

- Grodal, Birgit, \& Grodal, Torben (1998):

"Kønspolitisk kulisse", Politiken, 16.12.

- Henningsen, Inge (1999): “Om kvalifikationer og køn”, Kvinder, Køn \& Forskning, 99: 1, pp. 20-30.

· Lovforslag nr. L 200: Forslag til Lov om kunstig befrugtning i forbindelse med lægelig behandling, diagnostik og forskning m.v. Fremsat d. 7. 2. 1996 af sundhedsministeren. (Første behandling d. 23. 2. 1996.$)$

. Lovforslag nr. L 5: Forslag til Lov om kunstig befrugtning i forbindelse med lægelig behandling, diagnostik og forskning m.v. Fremsat d. 2. 10. 1996 af sundhedsministeren. (Første behandling d. 8.10.1996; anden behandling d. 29. 4.1997 og tredje behandling d. 27. 5. 1997.)

- Lov nr. 460 af 10. 6. 1997: Lov om kunstig befrugtning i forbindelse med lægelig behandling, diagnostik og forskning m.v.

- Lovforslag nr. L 61: Forslag til Lov om ændring af lov om kunstig befrugtning i forbindelse med lægelig behandling, diagnostik og forskning m.v. (Enliges adgang til behandling). Fremsat d. 7. 11. 1997. (Første behandling d. 21. 1. 1998.)

- Lovforslag nr. L 53: Forslag til Lov om ændring af lov om kunstig befrugtning i forbindelse med lægelig behandling, diagnostik og forskning m.v. (Enliges og lesbiskes adgang til insemination samt lægelig behandling). Fremsat d. 3. 4. 1998. (Første behandling d. 24. 4. 1998; anden behandling d. 16. 6. 1998 og tredje behandling d. 19. 6. 1998.)

- Nüchel Thomsen, Birgit, \& Hannestad, Lise (1999): "Apartheidstatus for kvinder", Politiken, 6. 2 .
. Smith, Eva (2000): "Børns eller fædres rettigheder?", Berlingske Tidende, 5. 2.

- Ståhle, Bertel (1998): Kvinder og mond $i$ dansk universitetsforskning i 1990'erne, Undervisningsministeriet, København.

\section{SUMMARY}

The article analyses two recent debates in the Danish parliament which both focussed on the significance of gender. One dealt with the idea that the government should earmark forty professorships for women since the percentage of women professors remains extremely low (6\%). The proposal was met with strong objections mainly arguing that quality and gender are not related. The second debate evolved around the Bill on assisted reproduction. In contrast, gender and quality were here articulated as two sides of the same coin. Only women in a steady relationship with a man were allowed medical assistance with insemination, etc. In confronting the two debates, we deconstruct the phallogocentrism and the contradictory kinds of essentialism that are embedded in the discourses of the majority of debaters.

Mette Bryld

Lektor v. Syddansk Universitet, Odense

Nina Lykke, dr. phil.

Professor v. Tema Genus, Linköping Universitet. 